\title{
An introduction to the problem of the conversion of structural components, including components manufactured by casting techniques
}

\author{
Wstęp do problematyki konwersji elementów konstrukcyjnych, \\ w tym elementów odlewanych
}

\begin{abstract}
Modern development of technology features not only dynamic changes aimed at improving the performance characteristics of structural components through the optimum selection of materials, adjustments in design, or upgrade of manufacturing processes, but also the increase of the economic impact resulting from these changes. All of these processes occur under one common name of conversion and have a simple or - more often complex character (due to the vast scope of changes introduced).

This article examines some basic definitions related to the concept of conversion and its association with innovative and intelligent solutions currently applied in materials engineering.

Due to a variety of problems, attention was focused on the core notions related to conversion. Basing on our own experience (i.e., on the experience of the Foundry Research Institute and AGH University of Science and Technology in Krakow) and also on foreign achievements in this particular field of knowledge (mainly coming from the US), the most interesting examples of the conversion of materials and design (in the authors' opinion) were discussed with reference to the methods of manufacture and possible interactions.
\end{abstract}

Keywords: materials engineering, material conversion, design conversion, process conversion, casting, aluminium alloys

\section{Streszczenie}

Współczesny rozwój techniczny charakteryzuje się nie tylko dynamicznymi zmianami, mającymi na celu polepszenie właściwości eksploatacyjnych elementów konstrukcyjnych - poprzez optymalny dobór materiału, korektę konstrukcji czy doskonalenie procesu wytwórczego, ale także wzrostem

Edward Czekaj, Prof. Ph.D. D.Sc. Eng., Stanisław Pysz Eng., Robert Żuczek M.Sc. Eng.: Foundry Research Institute, Krakow, Poland; Aldona Garbacz-Klempka, Ph.D. Eng.: AGH University of Science and Technology, Faculty of Foundry Engineering, Krakow, Poland; edward.czekaj@iod.krakow.pl 
efektów ekonomicznych, wynikających z dokonywanych zmian. Procesy te noszą nazwę konwersji i mają prosty lub - częściej - złożony (z uwagi na zakres dokonywanych zmian) charakter.

W artykule rozpatrzono podstawowe definicje związane z pojęciem konwersja oraz jego skojarzenia z innowacyjnymi i inteligentnymi rozwiązaniami - aktualnie stosowanymi w inżynierii materiałowej.

Ze względu na szeroki zakres zagadnienia, uwagę skoncentrowano na podstawowych pojęciach związanych z konwersacją. Opierając się na doświadczeniach jednostek badawczych polskich (Instytutu Odlewnictwa i Akademii Górniczo-Hutniczej im. S. Staszica w Krakowie) i zagranicznych (głównie amerykańskich) zaprezentowano ciekawsze - zdaniem autorów - przykłady konwersji materiałowych, konstrukcyjnych oraz tych związanych ze sposobami wytwarzania - w ich wzajemnej interakcji.

Słowa kluczowe: inżynieria materiałowa, konwersja materiałowa, konwersja konstrukcyjna, konwersja wytwórcza, odlewanie, stopy aluminium

\section{Introduction}

For many years, the problem of conversion has played an important part in modern engineering - both technical and economical. However, for Poland under the conditions of a market economy of specific importance, are the changes that determine the presence of economic entities on the market, as well as their ability to compete in the local (regional and national) scale or internationally. Conversion in the present meaning of the word relates to a widely understood innovation and intelligent development. Taken from highly developed countries, these terms are not only the embodiment of a nice slogan, but they have become a reality in operational programs for Polish industry in the years 2014-2020 [1, 2]. Yet, achieving the expected technical and financial effects requires the use of comprehensive and multi-faceted solutions, a short description of solutions is contained in this publication.

The presented material is addressed both to professionals connected with widely understood technology of casting or wrought processing, as well as to designers. Given the modern arsenal of possibilities of material selection and preparation methods (both traditional and customized), in conjunction with the computerized ability to simulate manufacturing processes and evaluation of loads in structural elements in operational conditions at the design stages and production launch, today - more than ever - the contact of specialist manufacturers with designers becomes necessary.

\section{Analysis of the concept of conversion}

The term conversion [from Latin conversio; French conversion] means change, exchange, replacement, reversion, transformation, adaptation. The word has different meanings in different fields of knowledge, being understood as [3, 4]:

- in chemistry - a process in which the components of two substances undergo a mutual exchange; 
- in physics - the transition of an atom from one energy state to another (e.g., by emission of an electron);

- in mathematics (logic) - a type of reasoning;

- in economics - change of conditions (e.g., the interest rate) and/or timing of the loan;

- in religion - change of religion (convert - a neophyte);

- in materials engineering.

In materials engineering (including metallurgy and foundry), the complex nature of the concept of conversion and an attempt to explain its meaning and offer its proper interpretation are the subjects of this study.

\section{Goals, measures, strategies, and costs of conversion}

To explain the meaning of the concept of conversion in materials engineering (based on the experience gained by the authors and by using data from source materials; e.g., [5-7]), it seems quite logical to first talk about the goals, measures, strategies, and costs of conversion.

\section{Conversion goals}

- reduce (or increase) the weight of the finished product or component, thus improving its economic and useful functionality;

- optimize product and component design;

- reduce the cost of manufacturing;

- provide longer service life and better safety and/or reliability of the semi-finished and finished parts of vehicles (land or water) as well as aircraft, machinery, and equipment;

- introduce a rational operating time of products, considered in terms of the manufacturing cost and rate of physical and moral aging;

- improve quality and raise productivity through the use of new materials, new methods for their manufacture, and the mechanization and automation of manufacturing processes;

- improve the ecological aspect of production and environmental protection;

- make regeneration of parts sufficiently easy and develop a closed cycle of their manufacture.

The goals of conversion can be set either individually or as a combination of several of the above mentioned. 


\section{Conversion measures}

- using common and advanced materials (metallic and non-metallic) of preset properties;

- implementating new, more efficient manufacturing techniques and methods of heat treatment;

- optimizing the parameters of the manufacturing process and heat treat-ment;

- using the latest computational techniques in the selection of materials, design, and tooling (e.g., foundry mold elements), allowing for the evolution of physical, chemical, mechanical, and technological properties of products in the course of their manufacture and stress distribution under operating conditions.

\section{Conversion strategies}

- material strategy: replacement of original material with new material offering better properties;

- structural (shape and form) strategy: distribution of material in product design properly adjusted to the load and stress distribution in individual product areas;

- manufacturing strategy: the choice of manufacturing processes integrating different functions (single-part strategy; aggregation - one part replacing many parts, fewer connections) and giving the highest possible material savings.

It is often necessary to use a combination of two or all three types of strategies.

\section{Total cost of implementation of the new or converted (cast) product design and technology}

The literature (e.g., [5-7]) states the following types of costs:

- engineering cost of design, testing, and calculations;

- material cost: the unit price of materials and additives (refiners, inoculants); decreasing the specific weight/density of material means higher unit cost (price $/ \mathrm{kg}$ ), changing in the following sequence: steel $\rightarrow$ aluminium alloy $\rightarrow$ magnesium alloy $\rightarrow$ titanium alloy;

- manufacturing cost: the price of tools and process inputs (costs of energy, personnel, external services, fixed costs, and other costs; additionally - insurance and taxes on profits).

The development of new or modified design often requires a compromise in the solutions adopted; manufacturing costs are reduced using materials of higher specific volume (e.g., aluminium alloy instead of steel). 


\section{Conversion versus innovation and smart growth}

Today, innovation (Latin - innovare, to renew) means, among others, new methods of production; but invention becomes innovation only when it is implemented in practical use. Innovation is an important source of economic growth and competitiveness [2].

In light of the definition provided by the Organization for Economic Cooperation and Development (OECD) [8] and the European Commission, there are four types of innovation related to [2]:

- product - making products with new or improved technical, functional, or performance characteristics;

- process - new or upgraded methods of production, changes in production technology; goals - higher quality and/or lower unit cost;

- marketing - changes in product appearance and/or design; also in its packaging, distribution, ways of promotion, and pricing strategy;

- organization - new ways to create business, changes in workplace organization, better means of shaping business relations with the environment; goals - among others - reduced administrative costs, increased productivity, lower cost of supplies.

One of the major concerns of the European Union in the financial perspective 2014-2020 is sustainable and smart growth, which should lead to the growth of economic competitiveness of the member states, to an increased number of jobs and improved standard of living. Nearly $76 \%$ of EU funds in research and innovation (originating from the European Regional Development Fund) will be used to support enterprises in their R\&D activities and to increase knowledge transfer to the industry. In the Operational Program Intelligent Development (coordinated by the Ministry of Infrastructure and Development), gaining new customers and markets will require research and experiments that will allow for going ahead of the competition and the introduction of unique products to the market [1]. A way to achieve these goals in foundries is (among others) the use of theoretical knowledge and practical abilities and skills to carry out experiments in the laboratory and/or industry, as well as the modeling of manufacturing processes and operations. In the latter respect, a new concept has arisen in the Foundry Research Institute in Krakow that is based on the hardware and software available. This concept may have a great impact on the design of new structural components and processes for their manufacture, and also on the widely understood problem of conversion regarding materials, structures, and/or technologies. The name of this concept is the Integrated System for Modeling of Materials and Process Engineering [9]. Figure 1 shows this concept in the form of a flow chart. 


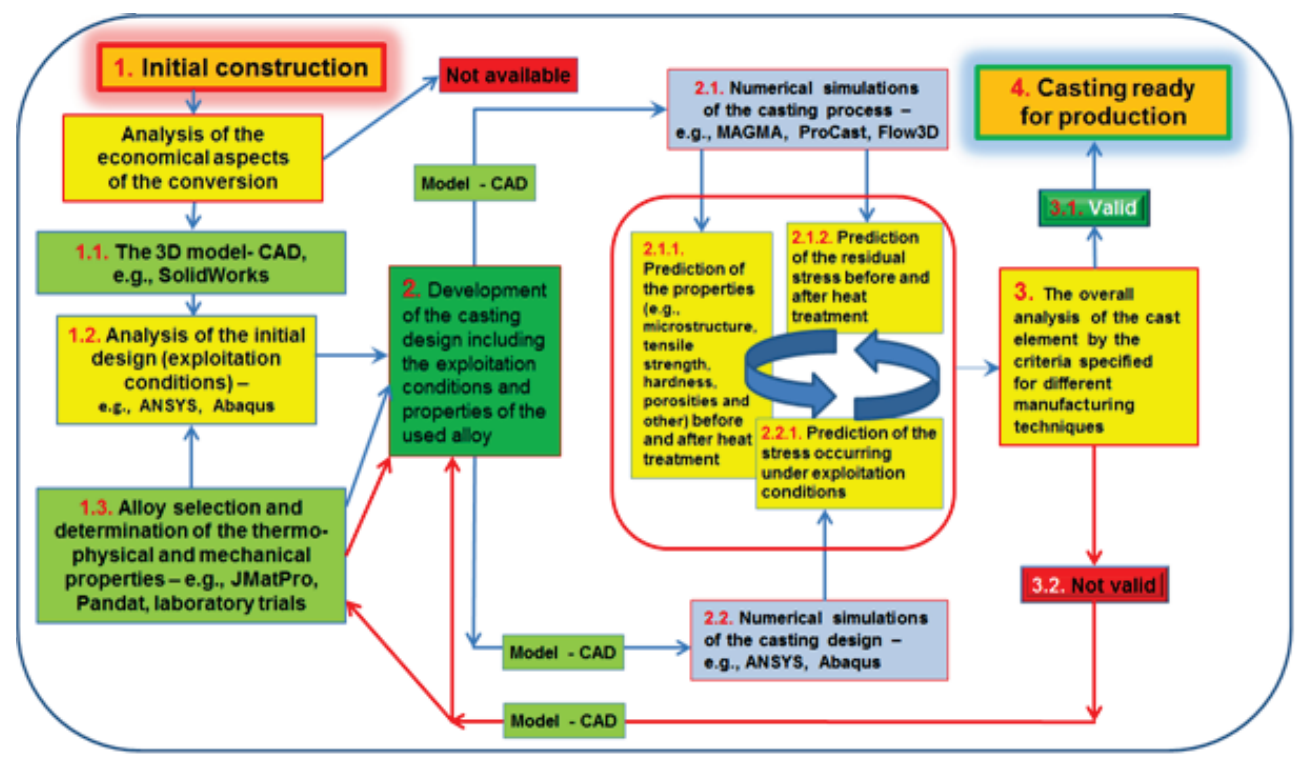

Fig. 1. Schematic representation of an integrated system for the design and material conversion using numerical calculations and laboratory research (developed by S. Pysz)

\section{Brief description of conversion types}

The analysis conducted in Section 4 of the concept of conversion used in materials engineering has allowed for the development of the three types of conversion with interactive links, proposed for use in the industrial practice and shown in the simplified scheme below (Fig. 2).

\section{CONVERSION OF STRUCTURAL COMPONENTS}

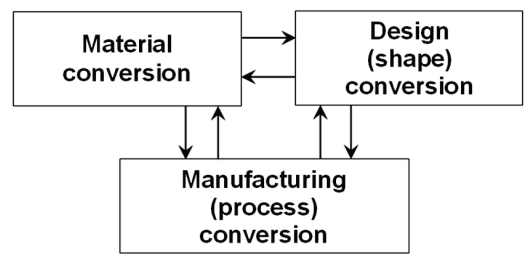

Fig. 2. Scheme showing interrelations existing between different types of conversion strategy

The following chapters present a short description of the different types of conversion, with a focus on metal products manufactured by casting technology. 


\subsection{Material conversion}

In the selection of alloy matrices (new or converted) and/or alloying elements for components made by casting, certain criteria are taken into account; mainly, those relating to the fundamental physical and mechanical properties as well as to product price.

Figure 3 shows, as an example, various elements selected for alloy matrices and/or alloying elements of proper density (specific gravity) and melting point.

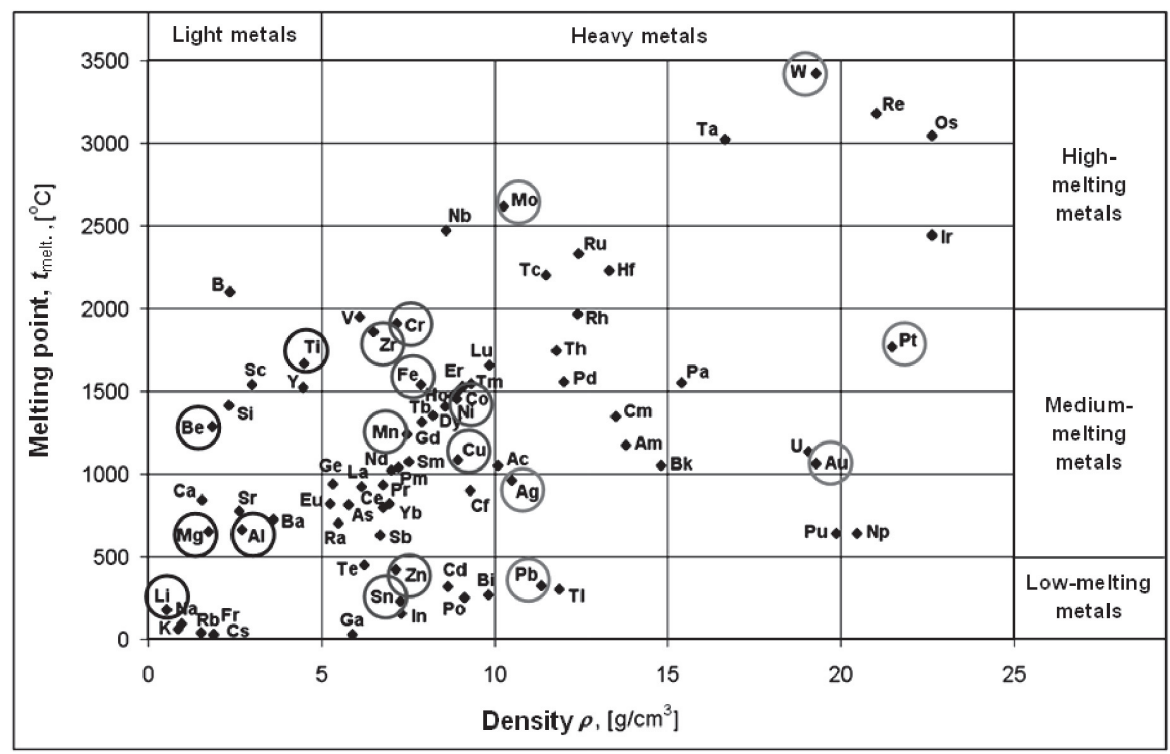

Fig. 3. Scheme showing classification of elements in terms of density and melting point; circles mark the most-common types of alloy matrices (own study, based on data taken from [10, 11])

In terms of density (which affects the weight of structural components), the following classifications of metals have been adopted:

- light metals $\left(\rho<5 \mathrm{~g} / \mathrm{cm}^{3}\right): \mathrm{Li}, \mathrm{Mg}, \mathrm{Al}, \mathrm{Be}, \mathrm{Ti}$;

- medium-heavy metals $\left(5 \mathrm{~g} / \mathrm{cm}^{3}<\rho<10 \mathrm{~g} / \mathrm{cm}^{3}\right)$ : $\mathrm{Sn}, \mathrm{Zn}, \mathrm{Cr}, \mathrm{Mn}, \mathrm{Fe}, \mathrm{Ni}, \mathrm{Co}, \mathrm{Cu}$;

- heavy metals $\left(\rho>10 \mathrm{~g} / \mathrm{cm}^{3}\right)$ : Ag, Au, Pb, Pt, Mo, W.

In terms of melting point (which affects the thermal regime of component operation and energy consumption during the melting process), the following classifications of metals have been adopted:

- low melting point metals $\left(t_{\text {melt }}<500^{\circ} \mathrm{C}\right) \mathrm{Li}, \mathrm{Sn}, \mathrm{Zn}, \mathrm{Pb}$;

- medium melting point metals $\left(500^{\circ} \mathrm{C}<t_{\text {melt }}<2000^{\circ} \mathrm{C}\right)$ : $\mathrm{Al}, \mathrm{Mg}, \mathrm{Cr}, \mathrm{Mn}, \mathrm{Fe}, \mathrm{Co}, \mathrm{Ni}, \mathrm{Cu}$, $\mathrm{Ag}, \mathrm{Au}, \mathrm{Pt}$;

- high melting point metals $\left(t_{\text {melt }}>2000^{\circ} \mathrm{C}\right): \mathrm{B}, \mathrm{Mo}, \mathrm{W}$. 
Currently, the choice of alloy matrix is mainly based on charts like these that (as an example) are shown in Figure 4.

a)

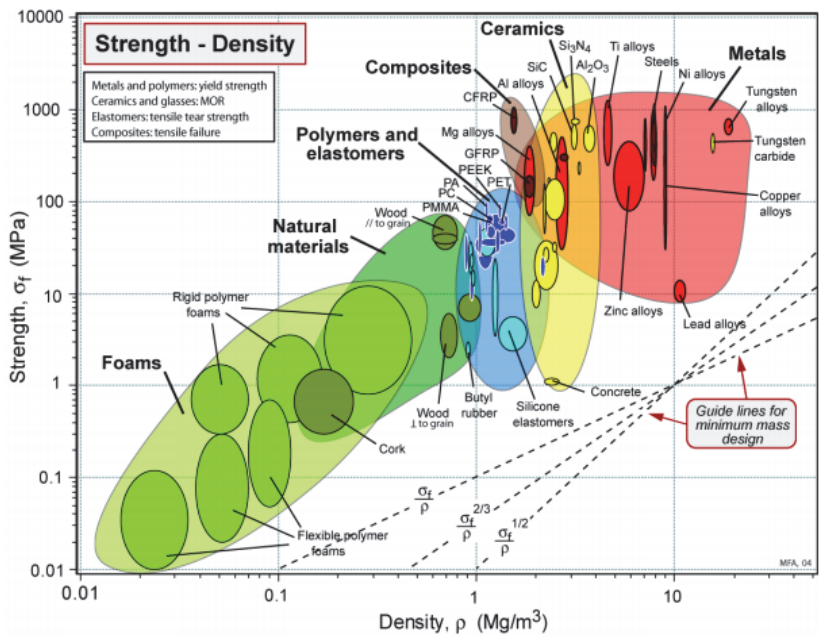

b)

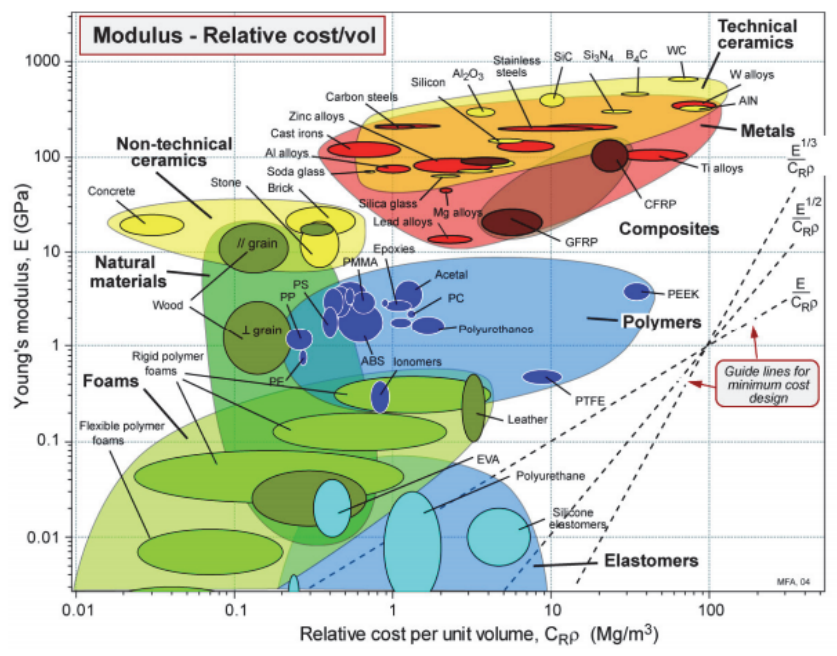

Fig. 4. Graphs showing principles of matrix selection for engineering materials (casting alloys) in a system of: a) strength - density; b) Young's modulus - relative cost per unit volume [12, 13]

In most cases, the performance of structural members does not depend on one property but on a complex set of various material characteristics. Therefore, in materials engineering, the preliminary assessment of modern materials is based on combinations of basic physical and mechanical properties, known as functionality index M (see Tab. 1). 

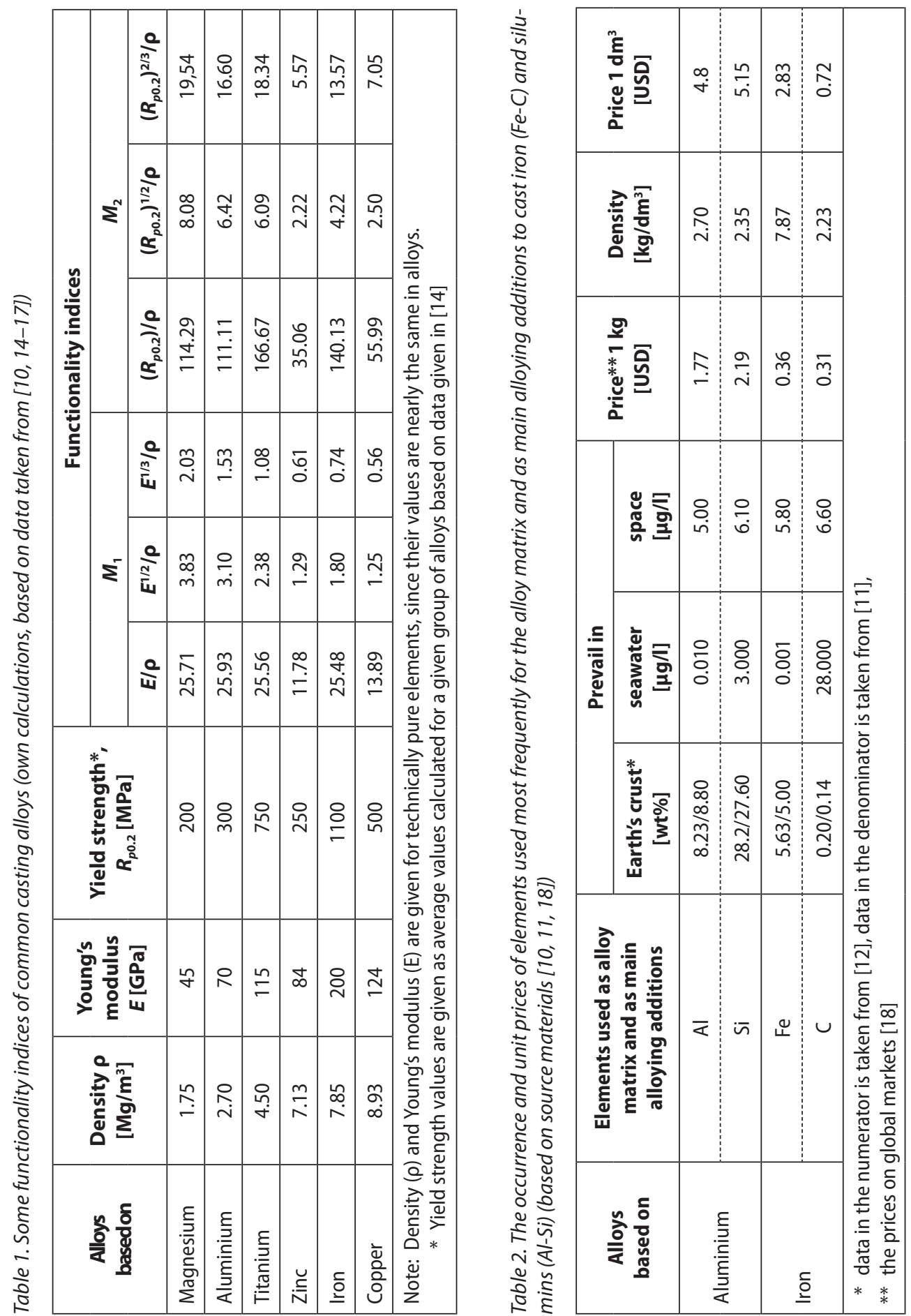
The power values of parameters $E$ and $R_{p 0.2}$ in Table 1 differ, depending on the type of load and destruction mechanism operating in a structural member. It is easy to note that light alloys based on titanium, aluminium, and magnesium have functionality indices comparable to and sometimes even higher than iron alloys. Much-lower positions in this comparison occupy the values of $\mathrm{M}$ obtained for alloys of copper and zinc.

A very important parameter in all conversion-related problems, demanding a lot of attention when the currently used materials are replaced with new ones, is the criterion of price. What is strongly recommended in this case is to examine not only the prices of materials per unit weight, but - first and foremost - the prices per unit volume. Table 2 gives an example of price comparison for the elements forming an alloy matrix and for the main alloying additions to cast iron and silumins; i.e., the two key casting materials.

The data in Table 2 confirm the well-known fact that the occurrence of an element does not translate directly into its price; the latter also being dependent on the volume and cost of extraction and processing. In the case of similar geometry and dimensions of a workpiece, the conversion of materials from cast iron to light (aluminium-based) alloy should not significantly affect the final cost (taking also into account other inputs; e.g., the melting process).

\subsection{Design (shape) conversion}

Historically, changes in design were introduced basing on the long experience of designers and close cooperation with experts (technicians and technologists) in the manufacture of metal items. As an example, Figure $5(a-d)$ shows the evolution of geometry and dimensions in pistons for I.C. engines covering a span of more than 100 years [19].

a)

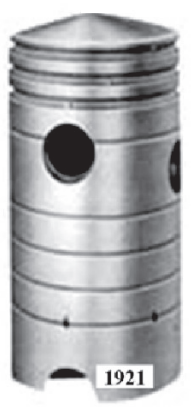

b)
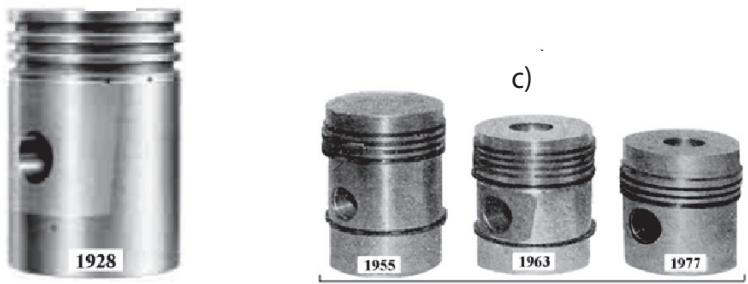

d)

Fig. 5. The changing design of aluminium alloy pistons over the years: a) first serial light alloy piston in Europe made by Mahle (Germany) [20]; b) automotive engine piston made by Mahle [21]; c) pistons for diesel engines made by VEB Druckguß- und Kolbenwerke (Harzgerode, Germany) [22]; d) modern Ecoform ${ }^{\oplus}$-type piston for petrol engines made by Mahle [20] 
Tracing the development of traction motors over the past century, one can observe a steady increase in power unit (currently reaching the level of $100 \mathrm{~kW} / \mathrm{l}$ [23], pressure (up to 200 bars), temperature $\left(400^{\circ} \mathrm{C}\right.$ and above), and speed of movement. In light of these facts, the changes shown in Figure 5 illustrates how the ever-decreasing weight must withstand and transfer the ever-increasing thermal and mechanical loads 19].

Examples of recent designs of light steel pistons for diesel engines used in passenger cars (implemented by KS Kolbenschmidt and Mahle in lot production in 2014) are presented in Figures 6 and 7. They are meant to ensure better engine performance when compared to pistons made from aluminium alloys, with reduced friction forces, less fuel consumption, and lower exhaust gas emissions.

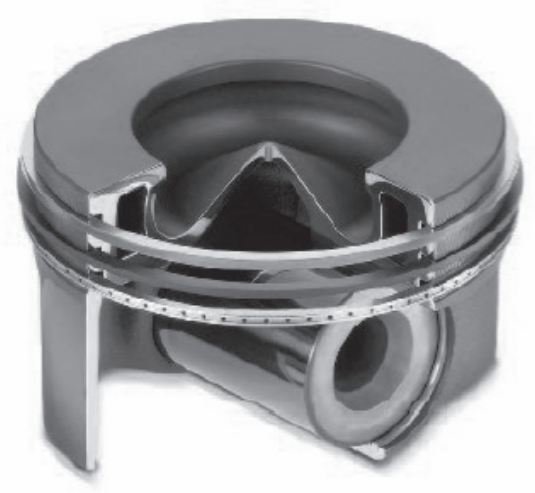

Fig. 6. Forged steel piston made by KS Kolbenschmidt [23]
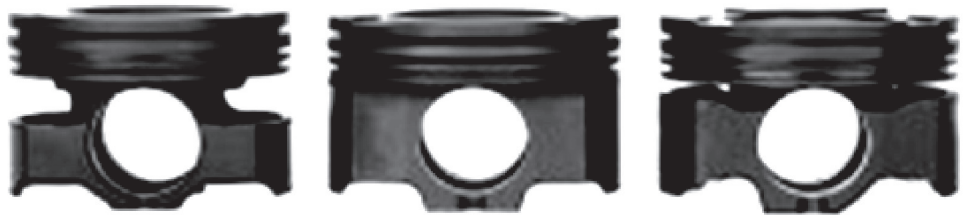

Fig. 7. Steel pistons made by Mahle [24]

The analysis of piston designs presented in Figures 5-7 shows a permanent tendency to reduce piston skirt height and restrict the piston-cylinder liner mate plane to a plane in the axis perpendicular to the axis of the bolt holes.

Changes in modern designs result not only from the knowledge and experience of technicians, engineers, and people from the world of science, but also from the implementation of computer programs in the design process (like SolidWorks, and of 
programs for the simulation of casting process, MAGMA, Procast, Flow3D and evaluation of the state of stress under static and/or dynamic loads, ANSYS, Abaqus); see diagram in Figure 1.

Figure 8 compares the changes in design of a structural component produced by the Lockheed Martin Corporation in the USA (manufacturer of parts for the aerospace industry) [25]. The component made by the traditional manufacturing process is compared with the same component made by the innovative incremental technique of $3 \mathrm{D}$ printing in titanium powder.

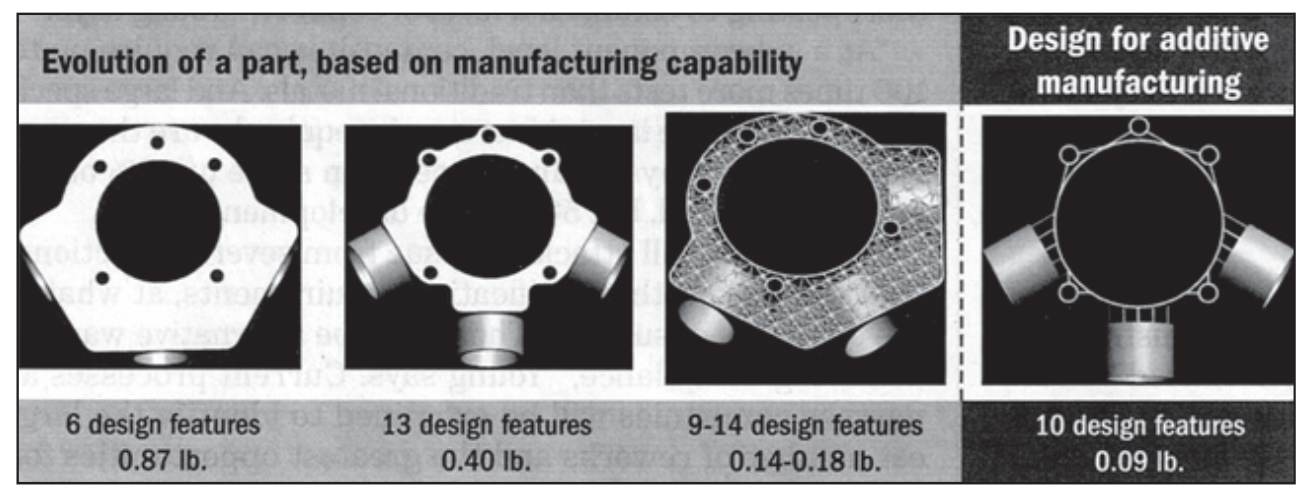

Fig. 8. Design of structural component compared between the traditional manufacturing process and incremental 3D printing technique [26]

Compared with traditional methods of production, the use of incremental techniques in the manufacturing process reduces energy consumption by 50 percent, while also providing a significant reduction (up to 90 percent) in the cost of materials [27]. The example in Figure 8 clearly shows how the strategies adopted in the choice of materials, design, and production are interrelated and, as a consequence, allow for the reduction of component weight and cost [26, 27].

\subsection{Manufacturing (process) conversion}

The flow chart in Figure 9 shows different manufacturing techniques applicable in the conversion of metal products. Every process for the production of structural components involves a number of different factors. Besides the type of material, other parameters of great significance include the following: a) overall dimensions, and indirectly also product weight; $b$ ) the shape of the product and complexity of its geometry (wall thickness variations); c) type of production; d) manufacturing accuracy; e) surface roughness; $f$ ) efficiency $[5,12,15,28]$. 


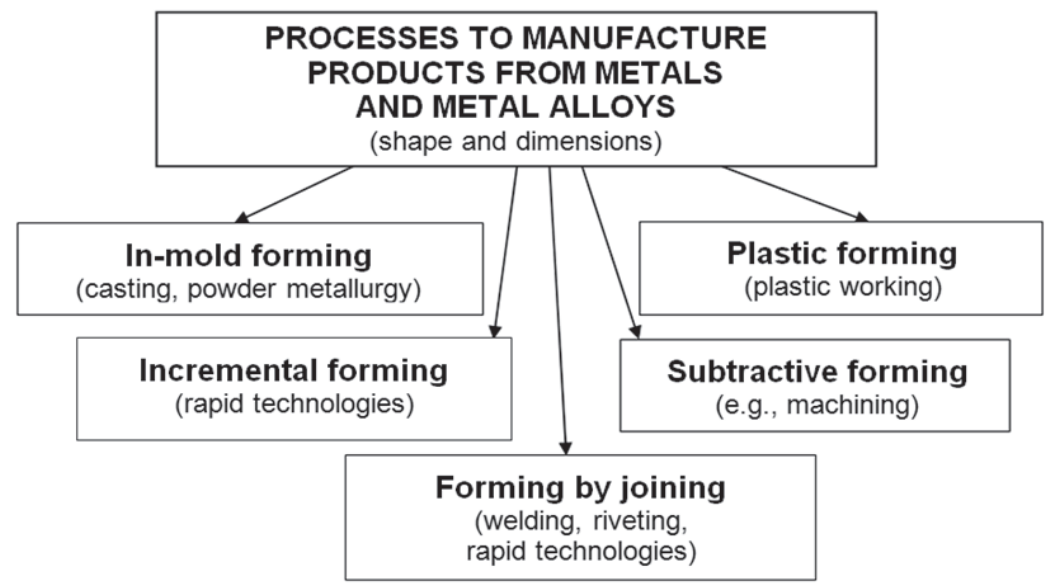

Fig. 9. Classification of various methods used in the manufacture of products from metals and metal alloys (own study, based on [5])

Similarly, the choice of casting process (see Fig. 10) is a derivative of many different factors. Even if only one type of material is used (e.g., aluminium alloy), the choice of best casting method is not a simple matter. An important issue here is to combine the technical and technological factors with economic aspects (Figs 11 and 12).

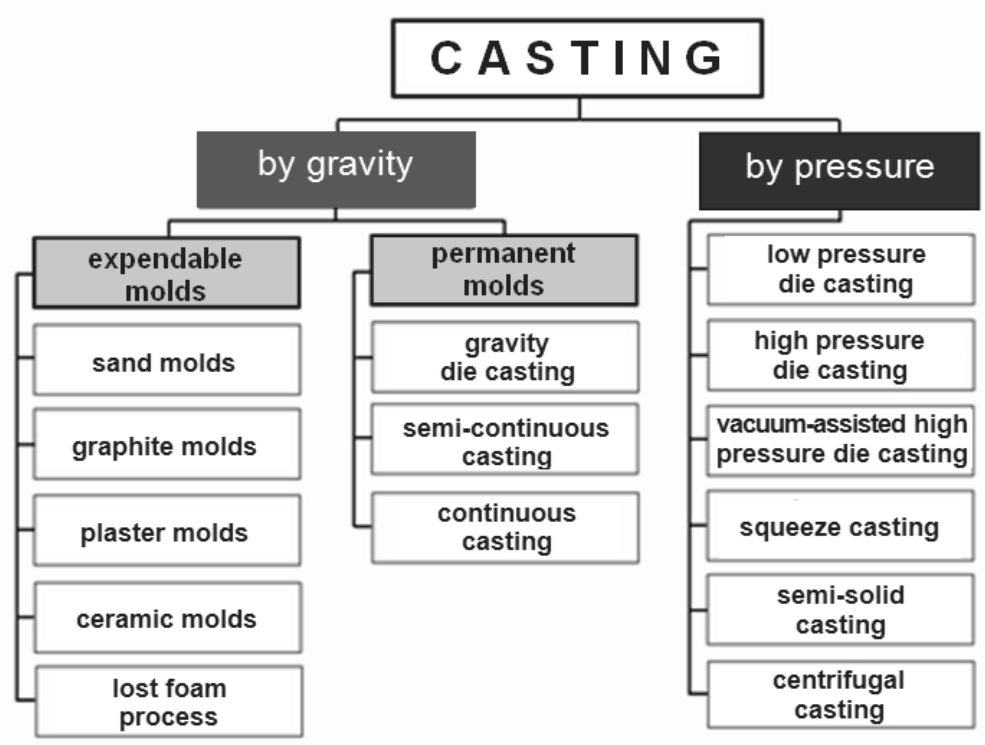

Fig. 10. Classification of the most important methods (common and special) for the casting of metals and metal alloys (own study, based on [5]) 


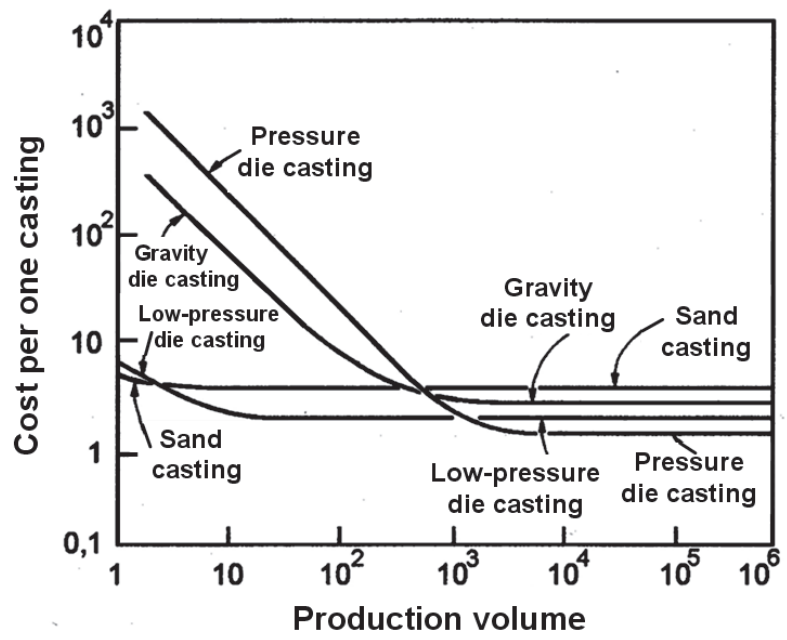

Fig. 11. The cost of casting aluminium alloy products related to the type of manufacturing process and production volume [15, 29]

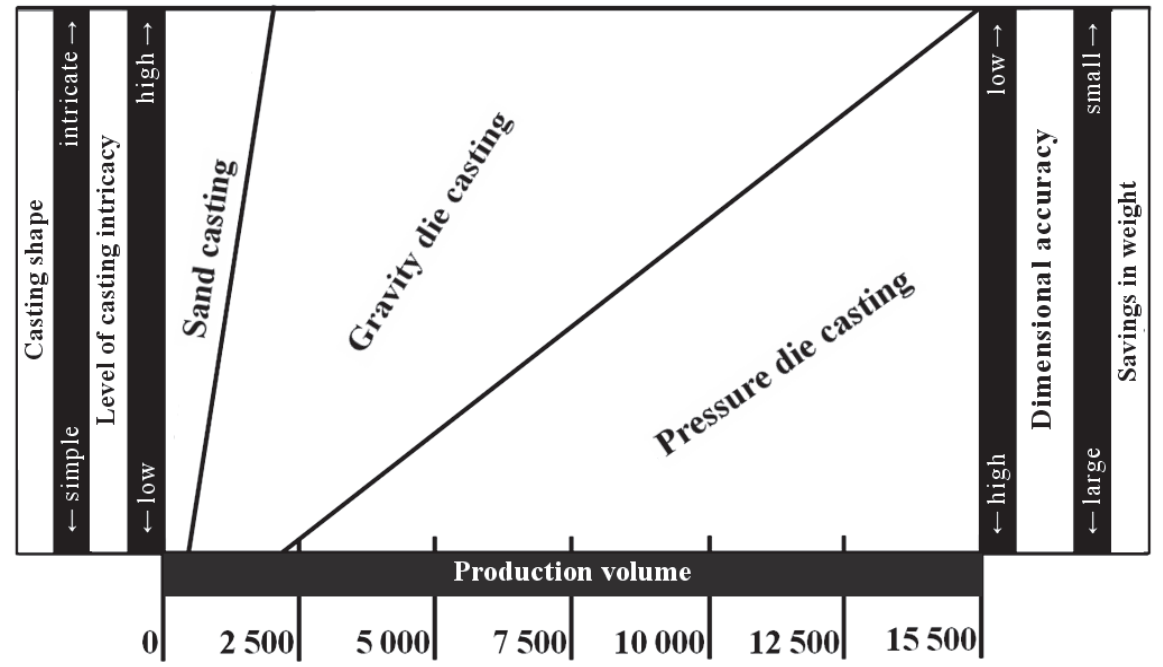

Fig. 12. Ranges of effectiveness of different aluminium alloy casting processes related to production volume batch size [30]

The curves in Figures 11 and 12 show that, in the case of large-lot production, the most cost-effective method for the manufacture of structural parts in aluminium alloys is pressure die casting; but in the case of piece production, the cheapest process is casting in sand molds. 
M.F. Ashby [15] and J.S. Colton [29] propose the following equation for calculating the cost falling to one casting $K_{o}$ :

$$
K_{o}=K_{m}+\frac{K_{\perp}}{p}+\frac{K_{R}}{W}
$$

where:

$K_{m}$ - cost of material (per unit) [USD/piece],

$K_{l}$ - investment costs (capital commitment) falling to particular casting process [USD],

$K_{R}$ - labor costs [USD/hour],

$p$ - batch size [pieces],

$w$ - productivity $\left[\mathrm{h}^{-1}\right]$.

The determination of the unit cost of the manufacture of structural components is important not only for a comparison of various manufacturing techniques but also for the selection of a casting process.

\section{Examples of conversion}

The following are three examples of conversion with varying degrees of complexity. They may serve as a model for similar tests made in the industrial foundry practice in Poland

Example 1 - Conversion of fabrications and weldments to castings (Fig. 13, Tab. 3).

a)

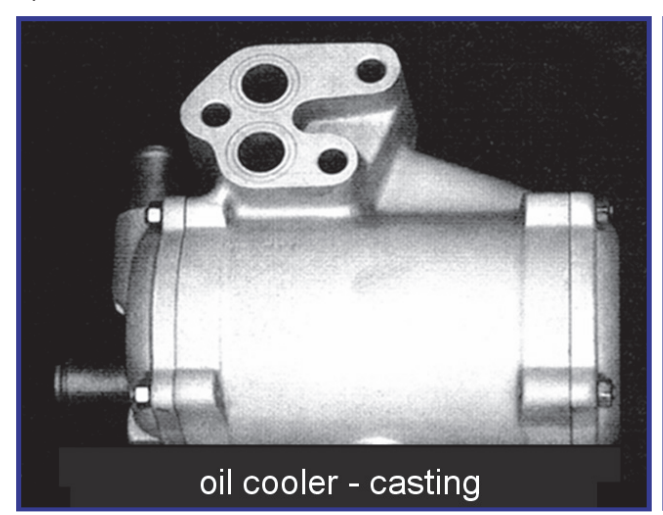

b)

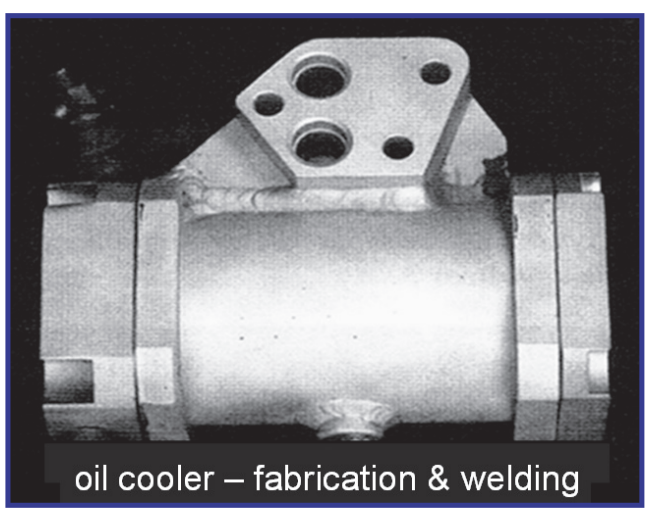

Fig. 13. Conversion of oil cooler fabrication and weldment (a) to casting (b) (courtesy of Foundry Research Institute in Krakow [31]) 
Table 3. Conversion of fabrications and weldments to castings - parameters and advantages

\begin{tabular}{|l|l|}
\hline \multicolumn{1}{|c|}{ Parameters } & \multicolumn{1}{c|}{ Advantages } \\
\hline material: AK93 (AISi9Cu3) aluminium alloy; & - savings in the consumption of base materials: \\
manufacturing process: gravity die casting of & from $10.4 \mathrm{~kg}-$ for pressed aluminium (AP) to \\
three elements: body with a bracket and two cov- & $3.5 \mathrm{~kg}$ for AK93 cast alloy; \\
ers (left and right); & \\
$\begin{array}{l}\text { weight: } 2.63 \mathrm{~kg}-\text { casting, } 2.68-\text { aluminium press- } \\
\text { ing (AP); }\end{array}$ & - reduced machining; \\
dimensions: body - $150 \times 170 \times 110 \mathrm{~mm}$, cover - & - improved aesthetics of the finished product; \\
$110 \times 110 \times 30 \mathrm{~mm}$ & - reduced labor consumption \\
\hline
\end{tabular}

\section{Example 2 - Conversion of bracket assembled from 11 welded steel components to one cast component (Fig. 14, Tab. 4).}

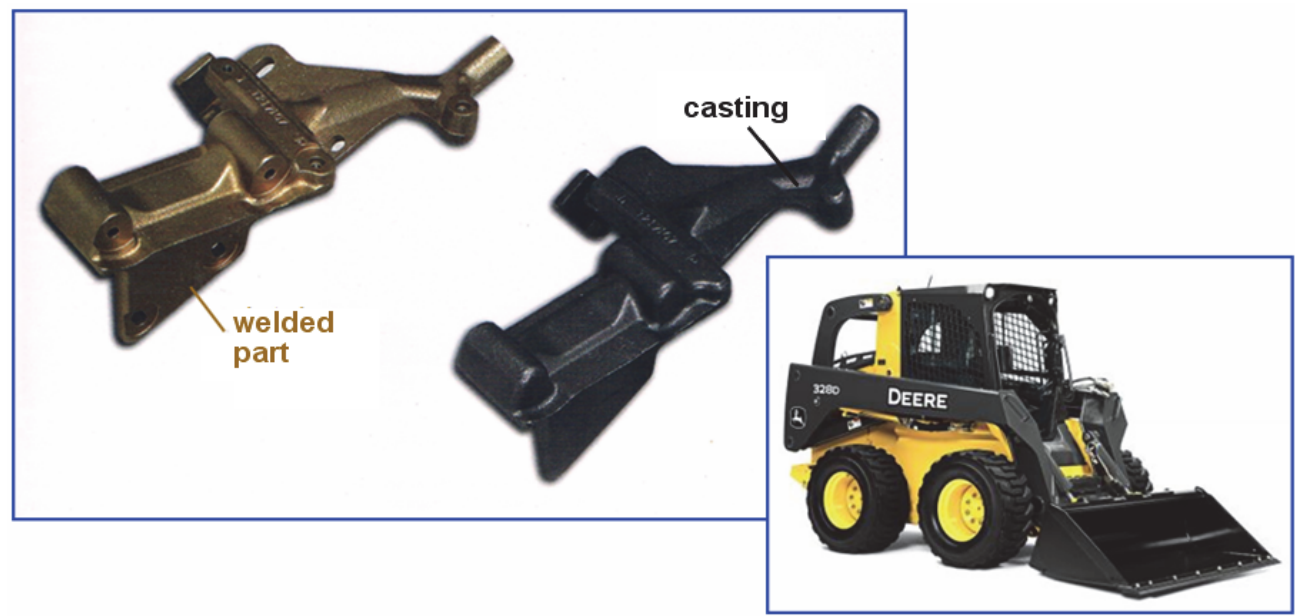

Fig. 14. Weld-to-cast conversion of bracket for motor generator operating in a mini-loader used in the construction industry (John Deere, USA) [32]

Table 4. Conversion of bracket assembled from 11 welded steel components to one cast component parameters and advantages

\begin{tabular}{|l|l|}
\hline \multicolumn{1}{|c|}{ Parameters } & \multicolumn{1}{c|}{ Advantages } \\
\hline $\begin{array}{l}\text { material: ductile iron; } \\
\text { manufacturing process: casting in sand molds; }\end{array}$ & - improved accuracy of performance and use of \\
$\begin{array}{l}\text { weight: } 10,7 \mathrm{lbs}(4,85 \mathrm{~kg}) ; \\
\text { dimensions: } 15 \times 6 \times 5 \mathrm{in} .\end{array}$ & -48 percent savings in production costs; \\
$(38.10 \times 15.24 \times 12.70 \mathrm{~cm})$ & -10 percent reduction in production waste \\
\hline
\end{tabular}



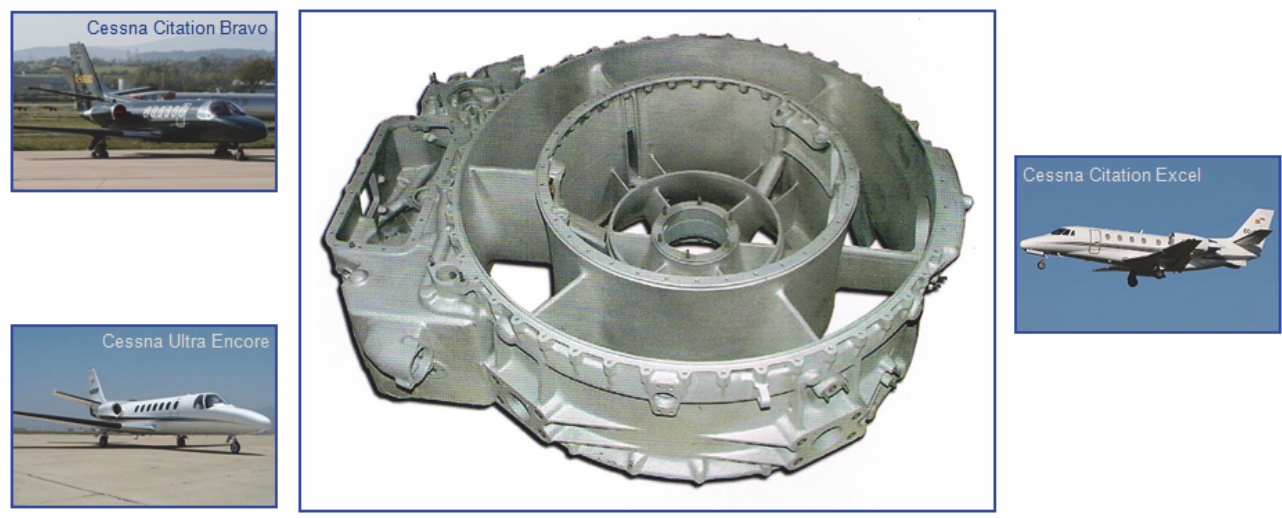

Fig. 15. Design conversion: combining frame air intake and auxiliary transmission drives in one casting [33-35]

Table 5. Conversion of the design of two parts of an aircraft engine to one casting - parameters and advantages

\begin{tabular}{|l|l|}
\hline \multicolumn{1}{|c|}{ Parameters } & \multicolumn{1}{c|}{ Advantages } \\
\hline material: ZE41 (Mg-Zn4.5-RE1.5) magnesium alloy; & - saving approx. 6 hours in production and assem- \\
manufacturing process: casting in sand molds & bly; \\
$\begin{array}{ll}\text { with resin binder }(\text { nobake process); } \\
\text { weight: } 97 \mathrm{lbs}(44 \mathrm{~kg}) ;\end{array}$ & - machining time reduced by at least 5 hours; \\
dimensions: $30 \times 11$ in. $(76,2 \times 28,0 \mathrm{~cm})$ & - weight of parts reduced by $11 \mathrm{lbs}(4.45 \mathrm{~kg})$. \\
\hline
\end{tabular}

\section{Final conclusions}

- The term conversion refers to many fields of knowledge. The data presented in this study shows that it is also widely used - both theoretically and practically - in the field of materials engineering (foundry practice included).

- The specified goals, measures, strategies, and costs of conversion are meant to serve as a tool in systematic analysis of some specific problems faced by the industry when possible conversion of material, design, and/or manufacturing process is considered (also taking into account various economic aspects).

- Examples presented in this study highlight the possibilities of achieving the technical and technological effects as well as organizational and economic benefits as a result of the application of simple and complex conversion procedures. 
- Following the example of the U.S. National Network of Manufacturing Innovation [26], it is proposed to create a network of scientific institutions, design offices, and industrial centers to raise innovativeness and competitiveness of Polish products, new or converted, made from metals and alloys.

- Further improvement in the selection of materials, structures, and methods for the manufacture of cast structural components can be achieved by (among others) the use of expert systems combined with relevant databases created at the Foundry Research Institute in Krakow, under the management of Professor Stanisława Kluska-Nawarecka.

\section{References}

[1] Fundusze Europejskie w Polsce. Biuletyn Informacyjny Nr 35. Wyd. Ministerstwa Infrastruktury i Rozwoju, Warszawa, październik 2014

[2] Wersa M.A.: Polityka innowacyjna. Wydawnictwo Naukowe PWN, Warszawa 2014

[3] Mały słownik języka polskiego, red. S. Skorupka et al. Państwowe Wydawnictwo Naukowe, Warszawa 1969

[4] Słownik wyrazów obcych. Państwowe Wydawnictwo Naukowe, Warszawa 1970

[5] Oczoś K.E., Kawalec A.: Kształtowanie metali lekkich. Wydawnictwo Naukowe PWN, Warszawa 2012

[6] Fertigungstechnik und Leichtbau. TU Dortmund Institut für Unformtechnik und Leichtbau, 2007, http:// www.leichtbau.de/ [21.07.2016]

[7] Klein B.: Leitbau-Konstruktion. 8 Aufl. Vieweg + Teunmer, Wiesbaden 2009

[8] Oslo Manual: Guidelines for Collecting and Interpreting Innovation Data. 3rd Edition. OECD Publishing, Paris 2005, DOI: http://dx.doi.org/10.1787/9789264013100-en

[9] Pysz S., Piekło J.: Zastosowanie zintegrowanego systemu modelowania i procesów inżynierskich (ICME) w odlewnictwie [The Application of Integrated Computational Materials Engineering (ICME) in Foundry Practice]. Prace Instytutu Odlewnictwa, 4, LIII (2013), 57-69

[10] Drits M.E. (ed.): Svoystva ehlementov: Spravochnik, Izd. Metallurgiya, Moskva 1985

[11] Mizerski W.: Tablice chemiczne. Wydanie IV zaktualizowane. Wydawnictwo Adamantan, Warszawa 2004

[12] Ashby M., Shercliff H., Cebon D.: Inżynieria materiałowa. Tom 1 i 2. Wydawnictwo Galaktyka, Łódź 2011

[13] Ashby M.: Material and Process. Selection Charts. Engineering Department Cambridge, Granta Design, January 2009; http://www.mie.uth.gr/ekp_yliko/2_materials-charts-2009.pdf [15.12.2015]

[14] Ashby M.F., Jones D.R.H.: Materiały inżynierskie - właściwości i zastosowania. Wydawnictwa Naukowo-Techniczne, Warszawa 1995

[15] Ashby M.: Dobór materiałów w projektowaniu inżynierskim. Wydawnictwa Naukowo-Techniczne, Warszawa 1998

[16] Nikulin L.V., Lipchin T.N., Zaslavskiy M.L.: Lit'e pod davleniem magnievykh spalvov. Izd. Mashinostroenie, Moskva 1978

[17] Oczoś K.: Kształtowanie ubytkowe tytanu i jego stopów w przemyśle lotniczym i technice medycznej. Część 1. Mechanik, 8-9 (2008) (Rok LXXXI), 639-656

[18] https://www/Ime.com [6.10.2014]

[19] Czekaj E.: Bezniklowe siluminy tłokowe o podwyższonej stabilności wymiarowej. Wydawnictwo Instytutu Odlewnictwa, Kraków 2011

[20] Mahle GmbH, Stuttgart 2005-2016; http://www.mahle.com [28.04.2015]

[21] Kolben- und Flugzeugteile aus Leichtmetall. Aluminium, 81, 9 (2005), 810-813

[22] Rasch K.: Zwanzig Jahre Kolbenentwicklung im VEB Druckguß- und Kolbenwerke Harzgerode. Gießereitechnik, 26, 6 (1980), 163-167 
[23] Innovative piston technology for passenger car and utility vehicles by KS Kolbenschmidt; http://www. kspg.com/fileadmin/media/kspg/Broschueren/Poduktbroschueren/KS_Kolbenschmidt/Kolben_Pkw/ ko_kombibrosch_EN_low.pdf [28.04.2015]

[24] Mahle: Steel pistons; http://www.mahle.com/mahle/en/products-and-services/passenger-cars/piston-systems/diesel-pistons/steel_pistons/ [28.04.2015]

[25] Lockheed Martin Corporation; http://www.lockheedmartin.com/us/who-we-are.html [28.04.2015]

[26] Warwick G.: Instituting Additive. Aviation Week \& Space Technology, March 31, 2014, 45

[27] Additive Manufacturing; http://www.roundtable.com/conferences-workshops/additivemanufacturing [28.04.2015]

[28] Dobrzański L.: Podstawy metodologii projektowania materiałowego. Wydawnictwo Politechniki Śląskiej, Gliwice 2009

[29] Colton J.S.: Casting Defects and Design Issues, ver. 2. ME 6222: Manufacturing Processes and Systems, Georgia Institute of Technology 2011; http://www-old.me.gatech.edu/jonathan.colton/me4210/castdefect.pdf [28.04.2015]

[30] LeiKom-Handbuch Produkt. Instrumente zur Entwicklung nachhaltiger Leichtbau-Komponenten. LeiKom, Februar 2010; http://www.cleaner-production.de/fileadmin/assets/pdfs/01RI05039_-_Abschluss bericht.pdf [2.08.2016]

[31] Stefański Z., Madej W.: Zamiana konstrukcji spawanej na odlewaną na przykładzie chłodnicy olejowej do samochodu ciężarowego. Przegląd Odlewnictwa, 9 (1998), 297-299

[32] Casting of the Year. Metal Casting Design \& Purchasing, May/June 2010, 25-27

[33] Casting of the Year. Best-In-Class (2006). American Foundry Society

[34] http://www.airplane-pictures.net (Cessna Citation Bravo) [28.04.2015]

[35] https://www.google.pl (Cessna Citation Excel, Cessna Citation Ultra Encor) [28.04.2015] 